\title{
Current Situation of Cassava Production, Constraints and Opportunities in Cambodia
}

\author{
Ou Wenjun ${ }^{1,3}$, Li Maofen ${ }^{2}$, Tin Maung Aye ${ }^{4, *}$, Sinath Srey $^{5}$ \\ ${ }^{1}$ College of Agronomy, Hainan University, Haikou, Hainan, China \\ ${ }^{2}$ Institute of Scientific and Technical Information, Chinese Academy of Tropical Agriculture Sciences, Danzhou, China \\ ${ }^{3}$ Tropical Crops Genetic Resources Institute, Chinese Academy of Tropical Agriculture Sciences/Key Laboratory of Conservation and \\ Utilization of Cassava Genetic Resources, Ministry of Agriculture, Danzhou, China \\ ${ }^{4}$ International Center for Tropical Agriculture, Hanoi, Vietnam \\ ${ }^{5}$ Cambodian Agricultural Research and Development Institute, Phnoom Penh, Cambodia
}

Email address:

t.aye@cgiar.org (T. M. Aye)

${ }^{*}$ Corresponding author

\section{To cite this article:}

Ou Wenjun, Li Maofen, Tin Maung Aye, Sinath Srey. Current Situation of Cassava Production, Constraints and Opportunities in Cambodia. Agriculture, Forestry and Fisheries. Vol. 5, No. 3, 2016, pp. 64-70. doi: 10.11648/j.aff.20160503.16

Received: April 28, 2016; Accepted: June 6, 2016; Published: June 8, 2016

\begin{abstract}
Within the framework of Cambodia-China-UNDP South-South Cooperation Cassava Project Phase II, the need assessment of cassava production in Cambodia was carried out in order to understand the current situation of the cultivation practices of cassava. A survey was conducted with 138 cassava growers in two provinces (Kampong Cham and Pailin) to understand their current situation of cassava cultivation practices and their constraints. The data were supplemented with semi-structured interviews with 12 key informants. Results indicate that cassava farmers in both Kampong Cham and Pailin provinces are smallholder-based, with an average owned cassava cultivated land of 1.01 ha and 3.55 ha, respectively. Farmers use different cassava varieties, which are most imported from Thailand and Vietnam. Most of the farmers in Kampong Cham province plant cassava stem cuttings horizontally, while all farmers in Pailin province grow them vertically. The planting space was similar (between $60 \mathrm{~cm}$ and $80 \mathrm{~cm}$ ) in both provinces. Farmers grow cassava continuously on the same field and do not intercrop with other crops. And farmers apply little or no organic and inorganic amendments to the cassava field. In 2013, the cassava production cost was US\$ $845 \mathrm{ha}^{-1}$ in Kampong Cham and US\$ $981 \mathrm{ha}^{-1}$ in Pailin. Of this, labor costs for harvesting accounts for $30 \%$ and $38 \%$ in these provinces, respectively. Farmers generated a gross margin of US\$ 682 ha $^{-1}$ in Kampong Cham and US\$ $834 \mathrm{ha}^{-1}$ in Pailin. In Cambodia, cassava yields can be markedly improved by growing better adapted cassava varieties and by improving soil fertility management and erosion control.
\end{abstract}

Keywords: Agronomic Practices, Smallholder Production Systems, Cassava Varieties, Soil Fertility, Production Costs

\section{Introduction}

Cassava (Manihot esculenta Crantz) is an important crop in tropical countries where it constitutes a key source of dietary energy and a potential raw material for industrial starch production [1, 2]. In Cambodia cassava is one of the most important upland crops and the crop has been both a mechanism for livelihood improvement at the household level, and a national source of income. As a relatively undemanding crop in terms of inputs, cassava can be considered an excellent pro-poor crop compared to other upland crops. The crop has high-yield potential and can be grown under a wide range of upland conditions. Cassava grows reasonably well in low soil fertility and in areas with low or unpredictable rainfall conditions which limit the growth of many other food and feed crops [3]. According to FAO data in 2012, Cambodia has the third highest cassava yields in Asia, after India and Laos. In Cambodia, however, the volatility in supply and demand in cassava markets has been the biggest problem in the production of cassava [4]. Within the framework of the Cambodia-China-UNDP South-South Cooperation Cassava Project - Phase II, the need assessment of cassava production 
in Cambodia was carried out in order to understand the current situation of cassava cultivation practices in Cambodia, and to identify the major constraints that farmers encounter in the production of cassava. This information will help to design specific interventions in terms of capacity development, in order to provide cassava farmers with the knowledge and tools to address those challenges and constraints.

This paper presents a needs assessment study of cassava production in Cambodia, which helps us to understand the current situation of cassava cultivation practices for the farmers in Cambodia. It specifically highlights the current agronomic practices in smallholder cassava production.

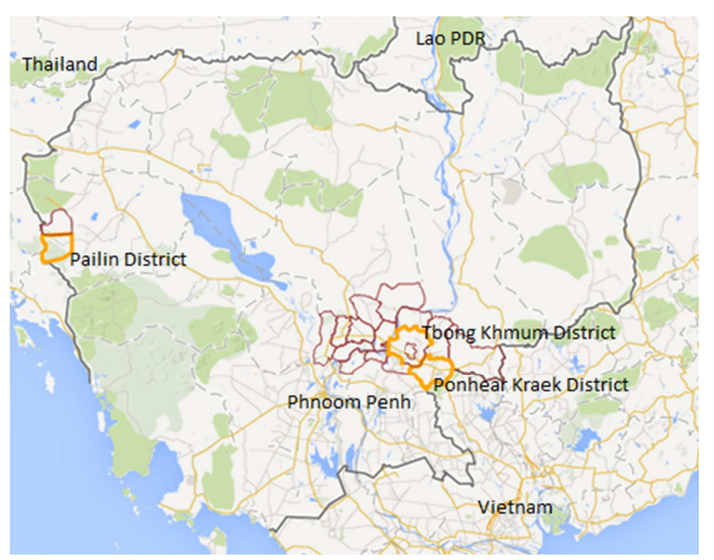

Figure 1. Four surveyed areas in Cambodia.

Table 1. Sample size of the study districts in Kampong Cham and Pailin provinces and Phnoom Penh city.

\begin{tabular}{|c|c|c|c|c|c|c|c|}
\hline \multirow{3}{*}{ Province } & \multirow{3}{*}{ District } & \multicolumn{5}{|c|}{ Number of samples } & \multirow{3}{*}{ Total } \\
\hline & & \multicolumn{3}{|c|}{ *Farmers } & \multirow{2}{*}{ Processors/exporters } & \multirow{2}{*}{ Key informants } & \\
\hline & & Small & Medium & Large & & & \\
\hline \multirow[t]{2}{*}{ Kampong Cham } & Tbong Khmum & 17 & 15 & 10 & 3 & 4 & 49 \\
\hline & Ponheal Kraek & 17 & 15 & 10 & 3 & 3 & 48 \\
\hline Pailin & Pailin & 17 & 15 & 10 & 4 & 3 & 49 \\
\hline Phnoom Penh & & & & & 2 & 2 & 4 \\
\hline Total & & 51 & 45 & 30 & 12 & 12 & 150 \\
\hline
\end{tabular}

Primary data was collected to obtain information about cassava cultivation practices, processing, marketing and post-harvest handling using both semi-structured interviews and questionnaires. Secondary data was also collected in the selected areas on rainfall, soil type, the history of cassava production, marketing, processing and any other data relevant to the study. 138 sampled households in Pailin and Kampong Cham provinces were surveyed, including those of cassava growers, processors and traders. In addition, two exporters in Phnoom Penh were interviewed.

The data collection was done through both semi-structured and structured interviews with farmers and guided questions with processors/exporters and other key informants such as active farmers, commune or village chiefs, cassava exporters, and provincial agricultural officers. Data collection was carried out during January-February 2014 in Kampong Cham and Pailin provinces. The training of enumerators on questionnaires was done in January 2014.

\section{Methodologies}

\subsection{Study Area}

Cambodia has varied topography and natural resources, and enjoys a tropical monsoon climate with marked wet and dry seasons [5]. The average yearly precipitation is $1,250-1,750$ $\mathrm{mm}$, humidity is $60 \%-80 \%$, and average annual temperature is $23-32{ }^{\circ} \mathrm{C}$. Cassava is grown on about four soil types in Cambodia: sandy, loamy, clayey and rocky. The soil color also differs across Cambodian provinces [5].

Two important cassava growing provinces, Pailin and Kampong Cham (Tbong Khmum and Ponheal Kraek districts), and Phnoom Penh city were selected as the study area for this study (Figure 1). These provinces both have a long history of cassava production and are currently the largest cassava growing areas in Cambodia. Besides cassava, farmers grow other crops, including rice, maize, mungbean, soybean, peanut and fruit trees.

\subsection{Methodologies}

The need assessment survey was conducted with 126 cassava growers and 12 processors/exporters to understand their current situation of cassava cultivation practices, processing and their constraints. The data were supplemented with semi-structure interviews with 12 key informants (Table 1).

\section{Results and Discussions}

\subsection{Farmer Household Profile}

Information on farmer livelihoods includes the demography of household members, their involvement in various kinds of agriculture, and farm activities, and the crops and livestock of the farms. 138 households were interviewed for the farmer survey. The average family size was 5 people. The male household heads were the dominant sources of information, accounting for about $90 \%$ of all households interviewed while about $10 \%$ of the household heads interviewed were women. $95 \%$ of household heads were between 24 and 68 year olds. Almost $71 \%$ of the total family members of the interviewed households were of the economically active population, aged between 15 to 60 year olds, while nearly $25 \%$ of the interviewed households consisted of children (under 15 year old). The majority of the household members had a low level 
of education. The percentage of household members having received no education or only primary education was more than $70 \%$. Only about $27 \%$ of household members surveyed could access secondary school education.

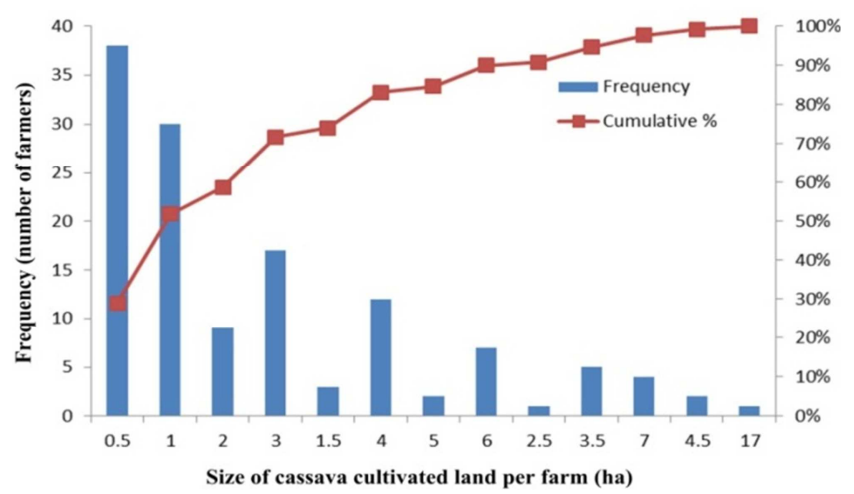

Figure 2. Distribution of cassava cultivated lands in Kampong Cham and Pailin provinces.

With regards to the agricultural and livestock activities of households surveyed, on average, about $50 \%$ of household members were involved in growing upland crops and more than $41 \%$ of households were involved in animal raising in Kampong Cham and Pailin provinces. The average size of paddy land was 1.15 ha per households in Kampong Cham, while the average size of paddy land was 1.88 ha per household in Pailin province. Cassava provided the most important household income for interviewed farmers, accounting for $84 \%$ in Kampong Cham and 98\% in Pailin. Cassava farmers in both Kampong Cham and Pailin provinces are considered smallholders. But the size of the cassava growing areas varies from one farmer to another. In Kampong Cham and Pailin provinces, overall 52\% of the cassava farmers owned cassava cultivated land of less than 1 ha, and $43 \%$ owned cassava cultivated land from 1 to 5 ha. The distribution of cassava lands is shown in Figure 2. Thus, cumulatively, $95 \%$ of the cassava farmers owned cassava cultivated land less than 5 ha. The results of the survey also show that most farmers (98\%) owned cassava land and very few farmers borrowed or rented land for cassava planting.

Regarding livestock production, pigs, cows, buffalos and poultry (chickens, ducks and geese) were commonly raised in both Kampong Cham and Pailin provinces, but more so in the former than in the latter. Raising chickens accounted for about
$87 \%$ and $76 \%$ of households, raising ducks accounted for about $39 \%$ and $20 \%$ of households, raising pigs accounted for about $16 \%$ and $4 \%$ of households, and those raising cattle made up $35 \%$ and $18 \%$ of households surveyed in Kampong Cham and Pailin, respectively.

\subsection{Cassava Production in Kampong Cham and Pailin Provinces of Cambodia}

The crop has been grown in Cambodia for several decades. However, prior to the $1970 \mathrm{~s}$ the crop was grown in small areas mainly as food for home consumption. Many upland farmers plant cassava, while only some farmers in lowland areas also grow this crop for home consumption. The total area in Cambodia used for cassava growing has increased significantly, from 19,600 ha in 2002 to 361,854 ha in 2012 , with root yields increasing from an average of $6.24 \mathrm{t} / \mathrm{ha}$ in 2002 to $23 \mathrm{t} /$ ha in $2012[6,7]$ (Figure 3).

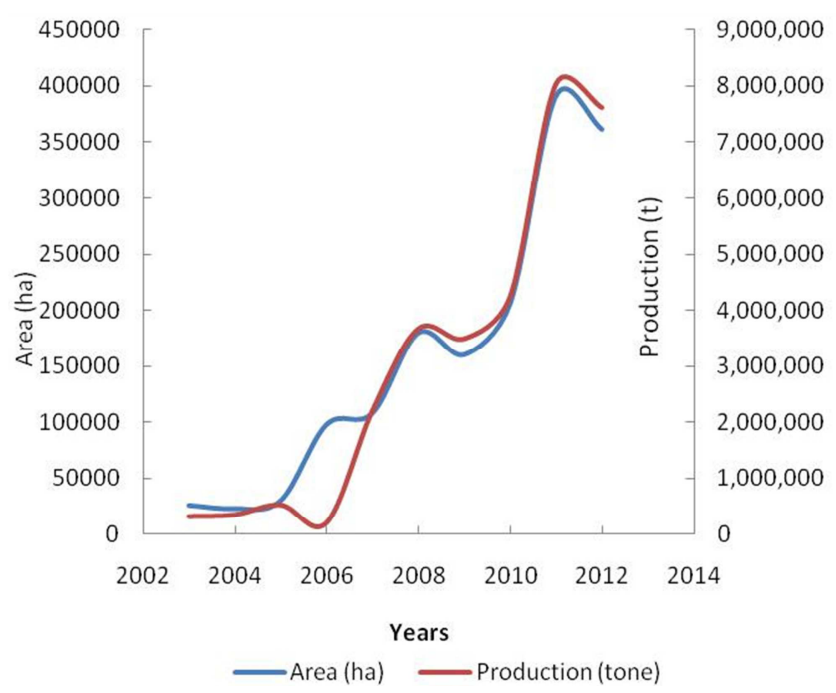

Figure 3. The planted area and average yields of cassava in Cambodia during 2003-2012.

In terms of total cultivated area, cassava has now become the second most important crop of Cambodia after rice. The cassava production (total cultivated areas, harvested areas, production and average yields) of individual provinces in Cambodia are presented in Table 2.

Table 2. Cassava cultivated area, harvested area, production and average yield in the main cassava producing provinces of Cambodia in 2013.

\begin{tabular}{|c|c|c|c|c|c|}
\hline Ranking (area) & Province & Total cultivated area (ha) & Total harvested area (ha) & Total production (t) & Average yield (t/ha) \\
\hline 1 & Battambang & 57,064 & 56,413 & $2,003,801$ & 35.5 \\
\hline 2 & Kampong Cham & 67,427 & 45,996 & 970,558 & 21.1 \\
\hline 3 & Bantheay-meanshey & 46,951 & 44,979 & 911,994 & 20.3 \\
\hline 4 & Kratie & 33,136 & 33,136 & 737,625 & 22.3 \\
\hline 5 & Kampong Thom & 29,270 & 29,270 & 420,883 & 14.4 \\
\hline 6 & Pailin & 20,160 & 20,160 & 705,600 & 35.0 \\
\hline
\end{tabular}

Source: (MAFF, 2013) [7]

Farmers in Kampong Cham started to grow cassava earlier than farmers in Pailin. About 66\% of the farmers in Kampong Cham province have grown cassava for 5 to 10 years while about $90 \%$ of the farmers in Pailin provinces have grown cassava less than 4 years (Table 3). In Kampong Cham province, cassava land was previously used in rotation for planting soybean, 
mungbean, and sesame production, while maize was mostly grown in Pailin province before planting cassava. Most farmers planted cassava as a mono-crop (54\% of farmers in Kampong Cham and $96 \%$ of farmers in Pailin). Only a few farmers were growing cassava as a mixed crop.

Table 3. Years of growing cassava by farmers in Kampong Cham and Pailin provinces.

\begin{tabular}{|c|c|c|c|c|}
\hline \multirow{2}{*}{ Years } & \multicolumn{2}{|c|}{ Kampong Cham } & \multicolumn{2}{|l|}{ Pailin } \\
\hline & Frequency & Cumulative\% & Frequency & Cumulative\% \\
\hline 1 & 2 & $2.27 \%$ & 7 & $15.22 \%$ \\
\hline 2 & 5 & $7.95 \%$ & 16 & $50.00 \%$ \\
\hline 3 & 5 & $13.64 \%$ & 11 & $73.91 \%$ \\
\hline 4 & 2 & $15.91 \%$ & 7 & $89.13 \%$ \\
\hline 5 & 14 & $31.82 \%$ & 2 & $93.48 \%$ \\
\hline 6 & 10 & $43.18 \%$ & 2 & $97.83 \%$ \\
\hline 7 & 10 & $54.55 \%$ & 0 & $97.83 \%$ \\
\hline 8 & 4 & $59.09 \%$ & 0 & $97.83 \%$ \\
\hline 9 & 4 & $63.64 \%$ & 0 & $97.83 \%$ \\
\hline 10 & 16 & $81.82 \%$ & 1 & $100.00 \%$ \\
\hline 11 & 2 & $84.09 \%$ & 0 & \\
\hline 12 & 4 & $88.64 \%$ & 0 & \\
\hline 13 & 1 & $89.77 \%$ & 0 & \\
\hline 14 & 0 & $89.77 \%$ & 0 & \\
\hline 15 & 3 & $93.18 \%$ & 0 & \\
\hline 16 & 0 & $93.18 \%$ & 0 & \\
\hline 17 & 0 & $93.18 \%$ & 0 & \\
\hline 18 & 2 & $95.45 \%$ & 0 & \\
\hline 19 & 0 & $95.45 \%$ & 0 & \\
\hline 20 & 4 & $100.00 \%$ & 0 & \\
\hline
\end{tabular}

The percentage of land used to grow cassava, land type and soil texture, and time of intercropping with cassava and associated crops in Kampong Cham and Pailin for cassava production is shown in Table 4. Many interviewed farmers in Kampong and Pailin did not use buffalo or cattle for land preparation but tractors or hand tractors.

Table 4. Land use before growing cassava, land type and soil texture, and time intercropping in relation to cassava planting in Kampong Cham and Pailin provinces.

\begin{tabular}{|c|c|c|}
\hline$\%$ of total interviewed farmers & Kampong Cham Province & Pailin Province \\
\hline \multicolumn{3}{|c|}{ Land uses before growing cassava (\%) } \\
\hline Soybean & 79.8 & 4.4 \\
\hline Mung bean & 22.5 & - \\
\hline Sesame & 21.3 & 22.2 \\
\hline Maize & 9 & 95.6 \\
\hline Peanut & 3.4 & - \\
\hline Cashew & 3.4 & - \\
\hline \multicolumn{3}{|l|}{ Land type (\%) } \\
\hline Very steep & 7.9 & 4.4 \\
\hline Steep & 49.4 & 42.2 \\
\hline Gently sloping & 18 & 40 \\
\hline Flat & 27 & 15.6 \\
\hline \multicolumn{3}{|l|}{ Soil type (\%) } \\
\hline Sandy & 11.2 & 4.4 \\
\hline Loamy & 18 & 42.2 \\
\hline Clay & 1.1 & 68.9 \\
\hline Rocky & 78.7 & 11.1 \\
\hline \multicolumn{3}{|l|}{ Soil colour $(\%)$} \\
\hline Red & 53.9 & 84.4 \\
\hline Grey & 25.8 & 11.1 \\
\hline Black & 27.0 & 26.7 \\
\hline White & 7.9 & 4.4 \\
\hline \multicolumn{3}{|l|}{ Planting time of intercrops* (\%) } \\
\hline$>2$ weeks before cassava planting & 56.2 & 50 \\
\hline 2 weeks before cassava planting & 3.1 & 50 \\
\hline 1 weeks before cassava planting & 9.4 & \\
\hline At the same time with cassava & 15.6 & \\
\hline 1 week after cassava planting & 12.5 & \\
\hline$>2$ weeks after cassava planting & 12.5 & \\
\hline
\end{tabular}

Intercrops with cassava: soybean, mungbean, maize, and sesame 
Table 5. Source of cassava stakes, storage places and duration of storage time of cassava stems in Kampong Cham and Pailin.

\begin{tabular}{lll}
\hline \% of total interviewed farmers & Kampong Cham & Pailin \\
\hline Source of cassava stakes & & \\
Owned stakes & 89.9 & 42.2 \\
From neighbours & 4.5 & 4.4 \\
Purchased from traders & 5.6 & 53.3 \\
Storage places of cassava stems & & \\
In open field & 51.7 & 95.6 \\
Under the shade & 13.5 & 2.2 \\
In storage shed & 57.3 & 2.2 \\
Duration of stem storage time & & \\
$<2$ weeks before planting & 4.5 & 2.2 \\
3-4 weeks before planting & 9.0 & 15.6 \\
5-12 weeks before planting & 13.5 & 80.0 \\
$>12$ weeks before planting & 73.0 & 2.2 \\
\hline
\end{tabular}

\subsection{Cassava Varieties in Cambodia}

Farmers use different cassava varieties, but they do not know which varieties are suitable for their specific agro-ecological conditions. The cassava varieties grown among the farmers were Malay, VN, Damglong Mi and an unknown variety in Kampong Cham province, and Kor Tal, Malay, VN, Rayong, Damlong Tuk, Huay Bong and a mixed variety in Pailin province. In Kampong Cham province, the most popular variety is Malay while Kor Tal variety is the most used in Pailin. More than $85 \%$ of farmers planted the Malay variety in Kampong Cham and $80 \%$ of farmers in Pailin province planted the Kor Tal variety. Both cassava varieties have high yield potential and high starch content; they were introduced by Thai and Vietnamese traders. However, most of these varieties have high HCN concentrations, and are mainly used for industrial purposes. Farmers in Kampong Cham province selected their cassava varieties because they were easy to grow ( $83 \%$ of farmers responded), produced high yield (64\% of farmers responded), and had high starch content (43\% of farmers responded), while farmers in Pailin paid more attention to high starch content $(91 \%$ of farmers responded), high yield $(73 \%$ of farmers responded), and easy to grow (27\% of farmers responded). Most farmers used their own cassava stems as planting material but about half of farmers in Pailin province bought cassava planting material from traders. In both provinces, most farmers also kept their cassava stems for more than four weeks before planting (Table 5).

\subsection{Current Agronomic Practices in Kampong Cham and Pailin Provinces of Cambodia}

There is a range of cultivation practices currently applied by the farmers but most farmers learn it from each other. For land preparation, almost all farmers used 4-wheel tractors in both Kampong Cham and Pailin. 97.8\% farmers in Pailin planted cassava on top of ridges while in Kampong Cham $74.2 \%$ farmers planted cassava in furrows. In Pailin, $48.9 \%$ of the interviewed farmers used contour ridges when the land was hilly or very steep. $45.8 \%$ of farmers in Kampong Cham used contour ridges on gently sloping land. Cassava was generally planted during March to June, but the common planting time in Kampong Cham was from April to June. For farmers in Pailin, cassava was planted mainly in March (Table 6). In Cambodia, three planting methods were used, i.e. horizontal, vertical and slanted (inclined). In Kampong Cham, about 97\% of interviewed farmers used the horizontal method while all interviewed farmers in Pailin applied the vertical method. In Kampong Cham, farmers normally planted one stake per hill and very few farmers used two stakes per hill. In contrast, farmers in Pailin only planted one stake per hill. Farmers used different spacing methods. The distance between plants in the row varied from 20 to $120 \mathrm{~cm}$, while the distance between rows were about 60 to $80 \mathrm{~cm}$.

Table 6. Percentage of farmers using various land preparation, planting, ridging and planting time methods of cassava production in Kampong Cham and Paili provinces.

\begin{tabular}{|c|c|c|c|c|c|c|c|}
\hline \multirow{2}{*}{ Province } & \multicolumn{4}{|c|}{ Land preparation methods (\%) } & \multicolumn{3}{|c|}{ Planting position $(\%)$} \\
\hline & Hoe & Hand tractor & 4-wheel tractor & No tillage & On top of ridge & In furrow & In digged-hole \\
\hline Kampong Cham & 4.5 & 10.1 & 82.0 & 3.4 & 4.5 & 74.2 & 21.3 \\
\hline Pailin & - & - & 100 & - & 97.8 & - & 2.2 \\
\hline \multirow{2}{*}{ Province } & \multicolumn{4}{|c|}{ Ridging methods (\%) } & \multicolumn{3}{|l|}{ Planting time $(\%)$} \\
\hline & Up-down & Contour & Parallel with plot & ders & Jan-Mar & Apr-Jun & Jul-Sep \\
\hline Kampong Cham & 2.4 & 45.8 & 51.8 & & 7.9 & 87.6 & 4.5 \\
\hline Pailin & 48.9 & - & 51.1 & & 91.1 & 8.9 & - \\
\hline
\end{tabular}

Many farmers in Cambodia usually grow cassava with little or no fertilizers [8]. According to the current farmers' survey, most farmers in Kampong Cham (90\% of interviewed farmers) and very few farmers in Pailin (less than $5 \%$ of interviewed farmers) used fertilizers. In Kampong Cham, most farmers use their owned farmyard manure as a source of organic fertilizers However, Urea, Diammonium phosphate (DAP), and compound fertilizer $\left(15 \mathrm{~N}-15 \mathrm{P}_{2} \mathrm{O}_{5}-15 \mathrm{~K}_{2} \mathrm{O}\right)$ were commonly used for cassava in Cambodia. The top dressing of organic fertilizer was broadcasting at planting. Urea and DAP 
fertilizers were applied at 2 months and 3-4 months after planting. Depending on the farmers' preferences, they would sometimes mix urea and DAP fertilizers. $15 \quad \mathrm{~N}-15 \quad \mathrm{P}_{2} \mathrm{O}_{5}-15$ $\mathrm{K}_{2} \mathrm{O}$ fertilizer was usually applied at 4 months after planting. Farmers could not estimate the rate at which the fertilizers were applied.

Costs of cassava production were calculated in Kampong
Cham and Pailin provinces. Cassava was a good cash crop and can be a major source of income for farmers. However, farmers required a considerable amount of investment to produce cassava (Table 7). However, the profit margins farmers can generate are strongly influenced by the price, which can vary from day to day, and sometimes with a quick drop and rise within a week or even within the same day.

Table 7. Gross margins of cassava production in Kampong Cham and Pailin in 2013.

\begin{tabular}{|c|c|c|c|c|c|c|}
\hline \multirow{3}{*}{$\begin{array}{l}\text { Province } \\
\text { Items }\end{array}$} & \multicolumn{3}{|c|}{ Kampong Cham } & \multicolumn{3}{|l|}{ Pailin } \\
\hline & \multirow{2}{*}{ Man-days/ha } & \multirow{2}{*}{$\begin{array}{l}\text { Labour cost } \\
\text { (\$/day) }\end{array}$} & \multirow{2}{*}{$\begin{array}{l}\text { Total cost } \\
\text { (\$/ha) }\end{array}$} & \multirow{2}{*}{ Man-days/ha } & \multirow{2}{*}{$\begin{array}{l}\text { Labour cost } \\
\text { (\$/day) }\end{array}$} & \multirow{2}{*}{$\begin{array}{l}\text { Total cost } \\
\text { (\$/ha) }\end{array}$} \\
\hline & & & & & & \\
\hline Land preparation by hand- or 4-wheel tractor & 1 hand tractor & 30 & 30 & 14-wheel tractor & 100 & 100 \\
\hline Cutting stakes & 9 & 5 & 45 & 9 & 5 & 45 \\
\hline Planting (digging \& planting) & 12 & 5 & 60 & 12 & 5 & 60 \\
\hline Fertilizers & & & 150 & & & 120 \\
\hline Insecticide spaying & 4 & 7.5 & 30 & 4 & 7.5 & 30 \\
\hline Herbicide spraying & 4 & 7.5 & 30 & 4 & 7.5 & 30 \\
\hline Harvesting (root digging \& cutting) & 50 & 5 & 250 & 50 & 7.5 & 375 \\
\hline Carrying & 10 & 5 & 50 & - & - & - \\
\hline Drying (Chip cutting \& drying) & 10 & 5 & 50 & 10 & 5 & 50 \\
\hline Transport by truck (6 t/truck) & 4 trucks & 31.25 & 125 & 5 trucks & 31.25 & 156.25 \\
\hline Total cost & & & 845 & & & 981.25 \\
\hline Price $(\$ / t)$ & & & 75.85 & & & 62.02 \\
\hline Gross income & & & 1526.86 & & & 1815.33 \\
\hline Gross margin (2013) & & & 681.86 & & & 834.08 \\
\hline
\end{tabular}

\subsection{Constraints of Cassava Cultivation in Cambodia}

One of main constraints of cassava production is the lack of suitable high-yielding varieties for specific agro-ecological conditions. Another main constraint of cassava production is the shortage of healthy and good-quality planting materials. Farmers are also not equipped with adequate knowledge and skills in soil fertility management. Management of soil fertility is of critical importance in sustainable cassava production, especially since it has traditionally been grown on less fertile soils usually with little or no fertilizer application.

Many farmers grow cassava on gently sloping to steep lands in the upland areas of Cambodia. Soil erosion is also a major constraint in maintaining cassava yields. General principles of farmer-friendly and cost-effective erosion control methods, such as intercropping, vegetative barriers and contour hedgerows, should be encouraged.

A number of cassava pests, including other mealybug species, mites and whiteflies, are a concern, as well as a number of diseases (such as witches-broom disease and Bacterial blight) in Cambodia. Several of these pests and diseases, if unchecked, appear likely to cause major declines in production and thus declines in the livelihoods of many poor farmers. Farmers in the study areas, particularly in Kampong Cham, reported to the Provincial Department of Agriculture (PDA) of Kampong Cham about significant losses of cassava yields due to the infestation of pests and diseases. The International Center for Tropical Agriculture (CIAT) also reported serious problems of emerging pests and diseases of cassava in Cambodia.

In addition, reduction in post-harvest losses, reduction in local small-scale processing, inadequate processing and use of cassava, lack of systematic planning and technical assistance to the cassava sector, and unstable prices of cassava are also constraints for the sustainable production of cassava in Cambodia.

\subsection{Opportunities of Cassava in Cambodia}

In Cambodia, cassava can produce a reasonable high yield with minimum inputs, and farmers can expect high yields from fields having a medium- to high-level of soil fertility and adequate soil moisture. But some agronomic management is still needed such as weeding, fertilization, etc. For example, early growth of cassava is relatively slow, thus weeds must be controlled during at least the first three months [9].

Cassava can be grown under a wide range of climate and soil conditions. Ideally, the soil temperature should be above $18^{\circ} \mathrm{C}$ and the annual rainfall should be above $1000 \mathrm{~mm}$. Cassava can grow well on well-drained sandy loam to clay loam soils, but cassava will not tolerate excess water. Generally cassava can be grown successfully in many parts of Cambodia. Cassava does not withstand flooding or very moist soil conditions over prolonged periods, but the crop is highly tolerant of drought.

(1). Yield improvement by growing the most adapted cassava varieties 
Cassava improvement in Cambodia should be reviewed to concentrate research on the development of varieties with the following desirable characteristics: (a) high yield and starch content, (b) suitable for use as food, animal feed or for the processing industry, and (c) resistance to pests and diseases. Selected varieties must have good rooting and high bud germination capacities. Cassava improvement in Cambodia could be strengthened with the collection and introduction of superior germplasm for improved yields and resistance against the cassava pests and diseases. Very few cassava varieties grow best in diverse agro-ecological conditions. Therefore, cassava varieties must be evaluated for the specific local soil and climatic conditions under which they will be planted, as well as for various end-uses, such as for human consumption, animal feeding or industrial processing. Major yield improvements can be expected with the development of best adopted varieties which have higher yield potential than many local varieties in Cambodia.

(2). Yield improvement by improving soil fertility and erosion control

Optimum fertilizer application rates for cassava production depend on specific locations, soils and production systems. Balanced application of N, P, K mineral fertilizers will increase yields by 50 to $100 \%$ in many areas and even more in very poor soils. The right rate of $\mathrm{K}$ application will also increase the root starch content and starch yields, and may also decrease its hydrogen cyanide $(\mathrm{HCN})$ content. However, over-fertilization of $\mathrm{N}$ may promote leaf and stem growth without increasing root yields. The application of $100 \mathrm{~kg} \mathrm{~N}, 20 \mathrm{~kg} \mathrm{P}_{2} \mathrm{O}_{5}$ and $120 \mathrm{~kg} \mathrm{~K}_{2} \mathrm{O}$ per hectare, plus returning plant tops to the soil, can result in yields of up to 40-50 t/ha of fresh cassava roots in many places of Cambodia.

(3). Productivity improvement by promoting cassava-based intercropping systems

Intercropping systems have many advantages for smallholder upland farmers, i.e. to reduce the risk of crop failure, to provide diversity of crops, and to obtain food or income at different times of the year. Intercropping makes the best use of available farm land and labour, may reduce weed problems, and if properly managed, may have a positive effect on soil fertility and soil erosion [10]. In general, intercropping is practiced when land is limited and labour is abundant. But this is seldom practiced on larger holdings and when labour is in short supply.

\section{Conclusions}

Cassava historically has had limited importance in the diet of Cambodians. Therefore, it would probably be difficult for cassava to gain acceptance as a major staple food in Cambodia. Potential future production of cassava in Cambodia will reflect current farmers' practices of cassava and other alternative upland crops. Therefore, it is important to promote newly introduced cassava varieties, appropriate strategies for cassava, and the transfer of improved production technologies for sustainable cassava-based production systems. Currently, such information is not available for agriculture researchers, extension staff, and farmers in Cambodia.
Ultimately the investment in cassava research and extension systems should be improved to ensure sustainable cassava production in Cambodia. The Farmer Participatory Research (FPR) approach and the training of trainers (ToT) and farmers are very essential to build the capacity for improving the cassava sector in Cambodia.

\section{Acknowledgements}

We are grateful to the farmers who actively collaborated in this study and taught us about the multiple roles of cassava within their farms. This study was part of the report presented to South-South China-Cambodia-UNDP Project (UNDP Cambodia).

\section{References}

[1] FAO, 1990. Roots, Tubers, Plantains and Bananas in Human Nutrition. Food and Agriculture Organization, Rome.

[2] Njie, D. N., Rumsey, T. R., Singh, R. P., 1998. Thermal Properties of Cassava, Yam and Plantain, Journal of Food Engineering, 37, 63-76.

[3] Søren, B. P. K., Torben, B.-T., Kjeld, R., Laura, V. R., Oumar, T. Cassava as an energy crop: A case study of the potential for an expansion of cassava cultivation for bioethanol production in Southern Mali. Renewable Energy, 2014, 66: 381-390.

[4] Huang, J., Liu, Y., 2005. Study tour report on cassava R and D in Cambodia. Guangxi Agricultural Sciences, (1), 63-66. (In Chinese).

[5] Lu, S., Shi, L., Tian, Y. et al, 2014. Production status and development opportunity of cassava in Cambodia. Agricultural Research and Application, (3), 60-63. (In Chinese).

[6] FAO, 2013. FAOSTAT statistical database (http://faostat.fao.org).

[7] MAFF, 2013. Annual Report for Agriculture Forestry and Fisheries, 2012-2013: Ministry of Agricultural Forestry and Fisheries, Phnoom Penh, Cambodia.

[8] Sopheap, U., Patanothai, A., Aye, T. M., 2012. Nutrient balances for cassava cultivation in Kampong Cham province in Northeast Cambodia. International Journal of Plant Production, 6 (1), 37-58.

[9] Aye, T. M., 2012. Cassava Agronomy: Land preparation, time and method of planting and harvest, plant spacing and weed control. In Cassava Handbook - A Reference Manual based on the Asian Regional Cassava Training Course held in Thailand (Editor: R. H. Howeler) Centro Internacional de Agricultura Tropical (CIAT, Apartado Aereo 67-13, Cali, Colombia, pp 588-612.

[10] Aye, T. M, Howeler, R. H., 2012. Cassava Agronomy: Intercropping Systems. In Cassava Handbook - A Reference Manual based on the Asian Regional Cassava Training Course held in Thailand (Editor: R. H. Howeler) Centro Internacional de Agricultura Tropical (CIAT, Apartado Aereo 67-13, Cali, Colombia, pp 613-625. 